\title{
Faktor-Faktor yang Mempengaruhi Permasalahan dalam Hasil Reviu Audit Intern
}

Sunti. A. Pratiwi ${ }^{1}$, Suratno $^{2}$

${ }^{1.2}$ Universitas Pancasila, Jl. Srengseng Sawah, Jagakarsa, Jakarta Selatan, 12640

INFO ARTIKEL

JEL Classsification:

M42

M48

Keywords:

human resources

competence,

information

technology, internal

control, internal audit.

\section{ABSTRACT}

This study aims to test both simultaneously and partially how big human resources competence, information technology and application of spi affects internal audit review results. The sample used in this study is the finance manager of 82 work unit of the ministry of health of the republic of indonesiathis study used a purposive sampling method and using a multiple linear regression analysis. Prior to the regression test, the data were tested beforehand using the classical assumption test. The result of research analysis shows that simultaneously human resources competence, information technology and application of spi have significant effect on internal audit result, The results of partial analysis that the competence of human resources, information technology and application of spi has a significant effect on internal audit review results.

\begin{abstract}
A B S T RA K
Penelitian ini bertujuan untuk menguji baik secara simultan maupun parsial seberapa besar kompetensi sdm, teknologi informasi dan penerapan spi mempengaruhi hasil reviu audit intern. Sampel yang digunakan dalam penelitian ini pengelola keuangan dari 82 satker kementerian kesehatan ri.penelitian ini menggunakan metode purposive sampling dan menggunakan alat analisis regresi linier berganda.sebelum dilakukan uji regresi, data terlebih dahulu diuji menggunakan uji asumsi klasik. Hasil analisis secara parsial bahwa kompetensi sdm, teknologi informasi dan penerapan spi berpengaruh secara signifikan terhadap hasil reviu audit intern.
\end{abstract}

\section{Pendahuluan}

Undang-undang Nomor 1 tahun 2004 tentang Perbendaharaan Negara, Menteri/Pimpinan Lembaga selaku Pengguna Anggaran/Pengguna Barang Kementerian Negara/Lembaga wajib menyelenggarakan akuntansi dan menyusun Laporan Keuangan Kementerian Negara/ Lembaga(LKK/L). sebelum disampaikan kepada Menteri Keuangan RI Laporan Keuangan harus direviu oleh Inspektorat Jenderal Kementerian Kesehatan RI selaku Aparat Pengawas Intern sesuai dengan Peraturan Pemerintah Nomor 8 Tahun 2006 tentang Pelaporan Keuangan dan Kinerja Instansi Pemerintah. Standar reviu laporan keuangan Kementerian/Lembaga diatur dalam Peraturan Menteri Keuangan nomor 255 tahun 2015.

*Email Korespondensi: ${ }^{1}$ sunti.arisandi27@gmail.com, ${ }^{1}$ soeratno_54@yahoo.com 
Laporan Keuangan yang disampaikan kepada Menteri Keuangan harus didasarkan pada disiplin ilmu akuntansi, sehingga memerlukan SDM yang kompeten agar dihasilkan laporan keuangan yang berkualitas, selain itu teknologi informasi banyak menawarkan manfaat seperti kecepatan pemrosesan transaksi dan penyiapan laporan transaksi dan penyiapan laporan, keakuratan perhitungan, penyimpanan data dalam jumlah besar, serta biaya pemrosesan yang lebih rendah. Selain itu Sisteem Pengendalian Intern juga berperan serta terhadap laporan keuangan dimana Sistem Pengendalian Intern merupakan filter untuk mencegah terjadinya penyimpangan dalam laporan keuangan.

Pada pelaporan atas Laporan Keuangan Kementerian/Lembaga masih sering ditemukan beberapa kelemahan seperti:

1. Ketidakakuratan nilai pada informasi laporan keuangan Kementerian/Lembaga yang disebabkan oleh kesalahan input, kesalahan rekapitulasi, atau kesalahan menyalin angka-angka pada dokumen sumber ke dalam system akuntansi instansi.

2. Ketidakandalan informasi laporan keuangan kementerian/lembaga yang disebabkan oleh ketidaklengkapan dokumen sumber dan ketidaksesuaiaan informasi antara dokumen.

3. Ketidakabsahan informasi laporan keuangan kementerian/lembaga yang disebabkan oleh ketidaksesuaian jenis transaksi dengan pertanggungjawaban biaya (misalnya, biaya perjalanan dipertanggungjawabkan dalam belanja pembelian alat tulis kantor) dan kesalahan otorisasi.

4. Ketidak sesuaian pengakuan, pengukuran, dan pelaporan transaksi dengan standar akuntansi pemerintah, misalnya pengukuran asset tetap menggunakan harga wajar, bukan harga perolehan.

Reviu yang dilaksanakan oleh Auditor Internal atas Laporan Keuangan Satker Semester I Tahun Anggaran 2017 masih terdapat permasalahan yang timbul dalam Laporan
Keuangan yang menyebabkan ketidakakuratan nilai, ketidak andalan, ketidak absahan, Ketidaksesuaian dengan Standar akuntansi Pemerintah dalam informasi laporan keuangan. antara lain, masih terdapatnya pagu minus pada aplikasi e-rekon, terdapat pengembalian belanja melebihi belanjanya pada beberapa Unit Akuntansi Kuasa Pengguna Anggaran/ Barang (UAKPA/B), adanya akun tidak lazim yang belum dapat diyakini ketepatan pencatatannya, terdapat kesalahan penggunaan akun pada pencatatan pendapan dan belanja, terdapat saldo tidak normal/bersaldo kredit pada akun-akun LO, masih terdapat penyajian Nilai Asset, Beban Penyusutan, beban barang, beban persediaan, beban Penyisihan Piutang Tak Tertagih, jurnal penyesuaian yang tidak dapat diyakini disebabkan masih terdapat kelebihan pembayaran, kesalahan akun dalam penyajian nya serta kurangnya dokumen sumber. Banyak satker yang belum melakukan rekonsiliasi, masih terdapat kurang saji pada kas

Selain itu masih tidak sesuainya Berita Acara Stock Opname dengan nilai persediaan barang, masih banyak obat dan alat medis yang sudah kedaluarsa tapi belum di keluarkan dari saldo persediaan. Masih terdapat beberapa Aset dicatat dan di gunakan pada satker yang berbeda. Terdapat Aset yang belum di register, karena kesalahan akun.

Tabel 1. Rekap Jumlah Permasalahan Hasil Reviu LK TA 201 s.d Semester I 2017

\begin{tabular}{lcc}
\hline \multicolumn{1}{c}{ Komponen } & 2016 & $\begin{array}{c}\text { Semester I } \\
2017\end{array}$ \\
\hline Laporan Realisasi Anggaran & - & 6 \\
Laporan Operasional & 1 & 4 \\
Laporan Perubahan Ekuitas & 7 & 3 \\
Neraca & 30 & 30 \\
Catatan atas Laporan & 0 & 0 \\
Keuangan & & \\
\hline
\end{tabular}

Beberapa penelitian telah melakukan penelitian yang terkait dengan Faktor-Faktor yang Mempengaruhi Permasalahan dalam Hasil Reviu Audit Intern, Hasil penelitiannya 
menunjukkan inkonsistensi terhadap faktorfaktor yang memperngaruhi Permasalahan dalam Hasil Reviu Audit Intern. Komarasaari (2016) hasil penelitian ini menunjukkan bahwa variabel pemanfaatan teknologi informasi dan pengendalian intern akuntansi berpengaruh secara signifikan terhadap keterandalan pelaporan keuangan pemerintah daerah. Sedangkan kapasitas sumber daya manusia tidak berpengaruh secara signifikan terhadap keterandalan pelaporan keuangan pemerintah daerah. Yusniar et al.,(2016) mengemukakan bahwa, sistem akuntansi pemerintahan dan pengendalian intern baik secara simultan maupun parsial berpengaruh terhadap good governance. sistem akuntansi pemerintahan, pengendalian intern dan good governance baik secara simultan maupun parsial berpengaruh terhadap kualitas laporan keuangan. Evicahyani dan Setiawina (2016) menyatakan Hasil analisis bahwa Kompetensi sdm, Penerapan Standar Akuntansi Pemerintah, Pemanfaatan Sistem Informasi Pengelola Keuangan Daerah (SIPKD) berpengaruh positif dan signifikan, terhadap kualitas Laporan Keuangan Pemerintah Daerah (LKPD) Kabupaten Tabanan baik secara langsung ataupun tidak langsung melalui variabel intervening, yaitu Penerapan Sistem Pengendalian Intern Pemerintah (SPIP). Agustiawan dan Rasmini (2016), hasil penelitian menunjukkan penerapan Sistem Akuntansi Berbasis Akrual, teknologi informasi dan sistem pengendalian intern berpengaruh positif pada kualitas laporan keuangan. Hasil lainnya menunjukkan kompetensi SDM mampu memperkuat pengaruh penerapan sistem akuntansi berbasis akrual, teknologi informasi, dan sistem pengendalian intern pada kualitas laporan keuangan. Kuasa et al., (2016) hasil dari penelitian ini menunjukkan Hasil penelitian menunjukkan bahwa kompetensi pejabat pengelola keuangan, regulasi dan pengawasan secara bersama-sama dan terpisah berpengaruh positif terhadap kualitas laporan keuangan Satuan Kerja Perangkat Daerah (SKPD) di lingkungan pemerintah Kabupaten Simeulue. Karmila et al., (2014) mengemukakan bahwa variable teknologi informasi berpengaruh signifikan terhadap keterandalan laporan keuangan sedangkan variable Kapasitas SDM dan Pengendalian Intern tidak berpengaruh signifikan terhadap keterandalan pelaporan keuangan SKPD pada Provinsi Riau. Nurillah dan Muid (2014) hasil penelitian ini mengungkapkan bahwa kompetensi SDM, SKPD, Pemanfaatan teknologi dan SPIP memiliki efek positif yang signifikan terhadap kualitas laporan keuangan pemerintahan daerah. Mahaputra dan Putra (2014) hasil analisis yang diperoleh dari penelitian ini bahwa kapasitas sumber daya manusia, pemanfaatan sistem informasi keuangan daerah, sistem pengendalian intern dan implementasi standar akuntansi pemerintahan berpengaruh positif dan signifikan pada kualitas informasi pelaporan keuangan di SKPD Kabupaten Gianyar. Widyaningsih et al.,(2011) mengemukakan bahwa Sistem Akuntansi Keuangan Daerah dan Sistem Pengendalian Intern Berpengaruh Signifikan terhadap kualitas akuntabilitas keuangan. Nugraheni dan Subaweh (2008) hasil dari penelitian ini menunjukkan Standar Akuntansi Pemerintahan dan Pengetahuan Pengelola Keuangan berpengaruh terhadap kualitas Laporan Keuangan. Arfianti dan Kawedar (2011) dalam penelitiannya menyimpulkan bahwa Sistem Pengendalian Intern berpengaruh positif signifikan terhadap keandalan pelaporan keuangan pemerintah daerah, sedangkan kualitas sumber daya manusia, pemanfaatan teknologi informasi, dan pengawasan keuangan daerah tidak berpengaruh.

\section{Telaah Teori dan Pengembangan Hipotesis}

\section{Hasil Reviu Audit Intern}

Reviu adalah penelaahan atas penyelenggaraan akuntansi dan penyajian Laporan Keuangan Kementerian/Lembaga oleh auditor Aparat Pengawasan Intern Kementerian/ 
Lembaga yang kompeten untuk memberikan keyakinan terbatas bahwa akuntansi telah diselenggarakan berdasarkan Sistem Akuntansi dan Pelaporan Keuangan Instansi dan Laporan Keuangan Kementerian/Lembaga telah disajikan sesuai dengan Standar Akuntansi Pemerintahan, dalam upaya membantu Menteri/ Pimpinan Lembaga untuk menghasilkan Laporan Keuangan Kementerian/Lembaga yang berkualitas.

Tujuan reviu adalah untuk membantu terlaksananya penyelenggaraan akuntansi dan penyajian Laporan Keuangan Kementerian/ Lembaga dan memberikan keyakinan terbatas mengenai akurasi, keandalan, dan keabsahan informasi Laporan Keuangan Kementerian/ Lembaga serta pengakuan, pengukuran, dan pelaporan transaksi sesuai dengan SAP kepada Menteri/Pimpinan Lembaga, sehingga dapat menghasilkan Laporan Keuangan Kementerian/ Lembaga yang berkualitas.

Prosedur dalam reviu Laporan Keuangan meliputi :

1) Kertas Kerja Reviu

Kertas Kerja Reviu menjelaskan mengenai pihak yang melakukan reviu, tingkatan unit akuntansi yang direviu, aktivitas penyelenggaraan akuntansi dan komponen akun Laporan Keuangan Kementerian/ Lembaga yang direviu, asersi yang dinilai dan langkah-langkah reviu yang dilaksanakan untuk menilai asersi dan hasil pelaksanaan langkah-langkah reviu dan simpulan serta komentar pereviu.

2) Catatan Hasil Reviu dan Ikhtisar Hasil Reviu

Untuk setiap unit akuntansi yang direviu, simpulan dalam KKR selanjutnya dituangkan dalam bentuk Catatan Hasil Reviu (CHR) dan Ikhtisar Hasil Reviu (IHR).

3) Laporan Hasil Reviu (LHR) Laporan Hasil Reviu sebagai gabungan CHR dan IHR sebagai gambaran menyeluruh terhadap hasil reviu yang dilakukan dan sebagai dasar membuat Pernyataan telah di reviu.

Adapun objek reviu laporan keuangan pada setiap unit akuntansi adalah sebagai berikut:

a. Laporan Realisasi Anggaran (LRA)

Laporan Realisasi Anggaran menyajikan ikhtisar sumber, alokasi, dan pemakaian sumber daya keuangan yang dikelola oleh pemerintah pusat/daerah, yang menggambarkan perbandingan antara anggaran dan realisasinya dalam satu periode pelaporan.

b. Laporan Perubahan Saldo Anggaran Lebih (Laporan Perubahan SAL) Laporan Perubahan Saldo Anggaran Lebih menyajikan informasi kenaikan atau penurunan Saldo Anggaran Lebih tahun pelaporan dibandingkan dengan tahun sebelumnya.

c. Neraca

Neraca menggambarkan posisi keuangan suatu entitas pelaporan mengenai aset, kewajiban, dan ekuitas pada tanggal tertentu.

d. Laporan Operasional (LO)

Laporan Operasional menyajikan ikhtisar sumber daya ekonomi yang menambah ekuitas dan penggunaannya yang dikelola oleh pemerintah pusat/ daerah untuk kegiatan penyelenggaraan pemerintahan dalam satu periode pelaporan.

e. Laporan Arus Kas (LAK)

Laporan Arus Kas menyajikan informasi kas sehubungan dengan aktivitas operasi, investasi, pendanaan, dan transitoris yang menggambarkan saldo awal, penerimaan, pengeluaran, dan saldo akhir kas pemerintah pusat/daerah selama periode tertentu.

f. Laporan Perubahan Ekuitas (LPE) Laporan Perubahan Ekuitas menyajikan informasi kenaikan atau penurunan ekuitas tahun pelaporan dibandingkan dengan tahun sebelumnya. 
g. Catatan atas Laporan Keuagan (Calk) Catatan atas Laporan Keuangan meliputi penjelasan naratif atau rincian dari angka yang tertera da-lam Laporan Realisasi Anggaran, Laporan Perubahan SAL, Laporan Operasional, Laporan Perubahan Ekuitas, Neraca, dan Laporan Arus Kas. Catatan atas Laporan Keuangan juga mencakup informasi tentang kebijakan akuntansi yang dipergunakan oleh entitas pelaporan dan informasi lain yang diharuskan dan dianjurkan untuk diungkapkan di dalam Standar Akuntansi Pemerintahan serta ungkapanungkapan yang diperlukan untuk menghasilkan penyajian laporan keuangan secara wajar.

\section{Kompetensi Sdm}

Kompetensi merupakan suatu karakteristik dari seseorang yang memiliki keterampilan (skill), pengetahuan (knowledge) dan kemampuan (abilty) untuk melaksanakan suatu pekerjaan (Hevesi,2005). Kompetensi sdm berperan penting dalam suatu pekerjaan, pegawai dengan kompetensi yang sesuai kebutuhan dalam pekerjaan nya di harapkan dapat menyelesaikan pekerjaan dengan baik, hal ini berpengaruh terhadap kualitas dari hasil pekerjaan.

Hasil penelitian Evicahyani dan Setiawina (2016), Agustiawan dan Rasmini (2016), Kuasa et al (2014), Nurillah dan Muid (2014), Mahaputra dan Putra (2014), Nugraheni dan Subaweh (2008), mengemukakan bahwa kompetensi SDM berpengaruh signifikan dan positif terhadap Kualitas Laporan Keuangan. Artinya semakin tinggi Kompetensi SDM maka akan semakin tinggi pula kualitas Laporan Keuangan yang dihasilkan. Berdasarkan penjelasan tersebut maka hipotesis yang dibangun adalah:

H1: Kompetensi SDM berpengaruh signifikan dan positif terhadap Hasil Reviu Audit Intern.

\section{Teknologi Informasi}

Menurut Williams dan Swayer (2003) yang dikutip Abdul Kadir dan Triwahyuni (2003), menjelaskan bahwa teknologi informasi adalah teknologi yang menggabungkan komputasi (computer) dengan jalur komunikasi berkecepatan tinggi yang membawa data, suara dan video. Menurut Thomson dan Baril (2003) mengemukaan bahwa teknologi informasi adalah perangkat keras dan perangkat lunak yang dikemas sebagai suatu alat untuk menangkap, menyimpan, memproses dan menghasilkan digital. Sedangkan menurut Wilkinson et all.,(2000) mendefinisikan teknologi informasi merupakan kombinasi teknologi gabungkan komputasi (computer) dengan jalur komunikasi berkecepatan tinggi yang membawa data, suara dan video. Menurut Thomson dan Baril (2003) mengemukakan bahwa teknologi informasi adalah perangkat keras dan perangkat lunak yang dikemas sebagai suatu alat untuk menangkap, menyimpan, memproses dan menghasilkan digital. Sedangkan menurut Wilkinson et all.,(2000) mendefinisikan teknologi informasi merupakan kombinasi teknologi computer yang terdiri dari perangkat keras dan lunak untuk mengolah dan menyimpan informasi dengan teknologi komunikasi untuk penyaluran informasi. Di sini teknologi penyaluran informasi. Di sini terknologi komunikasi digunakan sebagai alat penyaluran informasinya sedangkan informasinya diolah dan disimpan dalam computer. Teknologi informasi membawa dampak baik dalam suatu pekerjaan, dimana dengan kecanggihan teknologi dapat memudahkan, mempercepat pekerjaan yang sedang dikerjakan.Sehingga di harapkan pekerjaan yang dihasilkan dapat dijamin kualitasnya.

Hasil penelitian Komarasari (2016), Agustiawan dan Rasmini (2016), Karmila et al.(2014), Nurillah dan Muid (2014) menyatakan bahwa Teknologi Informasi berpengaruh signifikan dan positif terhadap Kualitas Laporan Keuangan. Sehingga semakin baik penerapan 
teknologi informasi maka laporan keuangan yang dihasilkan dapat dijamin kualitas nya. Berdasarkan penjelasan tersebut maka hipotesis yang dibangun adalah:

H2: Penerapan Teknologi Informasi berpengaruh signifikan dan positif terhadap Hasil Reviu Audit Internal.

\section{Sistem Pengendalian Internal}

Definisi Committee of Sponsoring Organizations of the Treadway Commission (COSO) tentang pengendalian intern dalam Auditing and Assurance Services: An Integrated Approach (Arens, A.A, Elder, R.J. and Beasley, M.S, 2008:432) sebagai berikut:

"Internal control is process, affected by entility's board of directors, management and other personnel, designed to provide reasonable assuranceregarding the achievementofobjectives in the following categories:Effectiveness and efficiency of operations, Realibillty of Financial Reporting, and Compliance with Applicable laws and regulations".

Sistem Pengendalian Intern (SPI) adalah proses yang integral pada tindakan dan kegiatan yang dilakukan secara terus menerus oleh pimpinan dan seluruh pegawai untuk memberikan keyakinan memadai atas tercapainya tujuan organisasi melalui kegiatan yang efektif dan efisien, keandalan pelaporan keuangan, pengamanan asset Negara, dan ketaatan terhadap peraturan perundang undangan. Sistem Pengendalian Intern melekat sepanjang kegiatan, dipengaruhi oleh SDM, serta hanya memberikan keyakinan memadai bukan keyakinan mutlak, sehingga dalam pengembangan dan penerapannya perlu dilakukan secara komprehensif dan harus memperhatikan spek biaya manfaat (cost of benefit), rasa keadilan dan kepatutan, perkembangan teknologi informasi dan komunikasi serta mempertimbangkan ukuran, kompleksitas, dan sifat dari tugas dan fungsi Instansi Pemerintah.

Dalam Peraturan Pemerintah Nomor 60 Tahun 2008 tentang Sistem Pengendalian Intern
Pemerintah, SPIP meliputi unsur sebagai berikut:

1) Lingkungan pengendalian

2) Penilaian risiko

3) Kegiatan pengendalian

4) Informasi dan komunikasi

5) Pemantauan

Sistem Pengendalian Intern berfungsi sebagai kontrol untuk memperkecil kesalahan. Dalam laporan keuangan dengan adanya SPI di harapkan dapat memperkecil kemungkinan salah saji dalam penyusunan laporan keungan.

Hasil penelitian Komarasari (2016), Yusniar et al., Agustiawan dan Rasmini (2016), Nurillah dan Muid (2014), Mahaputra dan Putra (2014), Widyaningsih et al., Arfianti dan Kawedar (2011) mengemukakan bahwa Penerapan SPI berpengaruh signifikan dan positif terhadap Kualitas Laporan Keuangan. Artinya semakin tinggi penerapan SPI maka laporan keuangan yang disusun semakin akurat dan terhindar dari salah saji. Berdasarkan penjelasan tersebut maka hipotesis yang dibangun adalah:

H3: Sistem Pengendalian Internal berpengaruh signifikan dan positif terhadap Hasil Reviu Audit Intern.

\section{Metode}

Populasi dalam penelitian ini adalah Pengelola Keuangan dari 418 (Empat Ratus Delapan Belas) Satker yang terdapat di Kementerian Kesehatan RI.Jumlah Pengelola keuangan dari 418 Satker adalah 1254 (Seribu Dua Ratus Lima Puluh Empat Satker). Adapun kriteria yang menjadi pertimbangan dalam pengambilan sampel adalah pengelola keuangan yang memiliki pengalaman minimal 1 tahun. Jumlah sampel yang diambil menggunakan rumus Slovin dengan margin/sampling error sebesar 10\% (Mulyanto dan Wulandari, 2010:103) sehingga diperoleh sebanyak 93 responden. Metode pengumpulan data dengan menggunakan kuisioner, wawancara dan telaah dokumen. 
Dalam Penelitian ini yang dimaksud Hasil Reviu Audit Internadalah Hasil Reviu Audit Intern (Reviu Laporan Keuangan) Satker yang di reviu oleh Auditor Internal Kementerian Kesehatan RI per semester setiap tahunmya. Dalam PMK Nomor 255/PMK.09/2015 terdapat lima hasil reviu yang dijadikan indikator, yaitu:

1. Hasil Reviu LRA UAKPA

2. Hasil Reviu LO UAKPA

3. Hasil Reviu LPE UAKPA

4. Hasil Reviu Neraca UAKPA

5. Hasil Reviu CaLK dan Lampiran LK

Kompentensi SDM (X1), Sukaningrum (2012) dalam Lestari(2013) Kompetensi SDM adalah kemampuan sumber daya manusia untuk melaksanakan tugas dan tanggungjawab yang diberikan kepadanya dengan bekal pendidikan, pelatihan, dan pengalaman yang cukup memadai. Variabel kompetensi sumber daya manusia diukur dengan instrument yang dibuat oleh Sukaningrum (2012) dimana terdapat empat indikator yaitu: (1) Pemahaman terhadap peraturan dan standar, (2) Interaksi dengan sistem, (3) Kontrol terhadap SDM, (4) Pendidikan dan training.

Teknologi Informasi (X3) tidak hanya dimanfaatkan pada organisasi bisnis tetapi juga pada organisasi sektor publik, termasuk pemerintahan. Dalam penjelasan Peraturan Pemerintah No. 56 Tahun 2005 tentang Sistem Informasi Keuangan disebutkan bahwa untuk menindaklanjuti terselenggaranya proses pembangunan yang sejalan dengan prinsip tata kelola pemerintahan yang baik (Good Governance), pemerintah, dan pemerintah daerah berkewajiban untuk mengembangkan dan memanfaatkan kemajuan teknologi informasi untuk meningkatkan kemampuan mengelola keuangan daerah, dan menyalurkan informasi keuangan daerah kepada pelayanan publik. Pemerintah perlu mengoptimalisasikan pemanfaatan kemajuan teknologi informasi untuk membangun jaringan sistem informasi manajemen dan proses kerja yang memungkinkan pemerintahan bekerja secara terpadu dengan menyederhanakan akses antar unit kerja (Nurillah dan Muid - 2014). Indikator variabel Teknologi Informasi mencakup :

1. Intensitas dan Frekuensi penggunaan computer

2. Jumlah jenis perangkat lunak yang digunakan

3. Otorisasi penggunaan computer / akses data (Authorization)

4. Adanya kemudahan menentukan data dan letak data (Locabiliy of data)

5. Kualitas data yang dihasilkan (Quality)

6. Kepercayaan terhadap system (System Reliability)

7. Kesesuaian data yang dihasilkan (Data Compability)

8. Kemudahan penggunaan hardware dan software dan kemudahan pelatihan (Easy of Use I Training)

Penerapan Sistem Pengendalian Intern (X4) diatur dalam PP Nomor 60 tahun 2008, SPIP diterapkan untuk mencapai tujuan organisasi melalui proses integral pada tindakan dan kegiatan oleh pimpinan dan seluruh pegawai secara terus menerus untuk memberikan keyakinan memadai yang dilakukan melalui kegiatan-kegiatan yang efektif dan efisien, pelaporan keuangan yang disajikan secara andal, pengamanan terhadap asset negara serta mentaati peraturan perundang-undangan yang berlaku. Berdasarkan Peraturan Pemerintah Republik Indonesia Nomor 60 Tahun 2008 bahwa pengendalian intern merupakan suatu proses yang dipengaruhi oleh SDM dan system teknologi informasi yang dirancang untuk membantu suatu organisasi dalam mencapai tujuan tertentu. (PP No. 60 Tahun 2008). Variabel Penerapan Sistem Pengendalian Intern dalam penelitian ini diukur dengan menggunakan instrument yang dikembangkan oleh Lestari (2013), yaitu (1) Lingkungan Pengendalian, (2) Penilaian Risiko, (3) Kegiatan Pengendalian, (4) Informasi dan Komunikasi (5) Pemantauan.

Data dalam penelitian ini menggunakan data berskala ordinal. Skala ordinal adalah 
data yang memiliki kategori dan orde/tingkatan tertentu (Mulyanto dan Wulandari, 2010:85). Pengukuran masing-masing variable dalam penelitian ini menggunakan skala Likert lima poin yaitu: 1 = sangat tidak setuju (STS), 2 = tidak setuju (TS), $3=\operatorname{netral}(\mathrm{N}), 4=\operatorname{setuju}(\mathrm{S}), 5$ = sangat setuju $(\mathrm{SS})$.

Sebelum digunakan sebagai instrumen penelitian, maka dilakukan uji validitas dan uji reliabilitas. Validitas menunjukkan seberapa nyata suatu pengujian mengukur apa yang seharusnya diukur. Validitas berhubungan dengan ketepatan alat ukur, kenyataan (actually) dan tujuan dari pengukuran. Sementara reliabilitas adalah kemampuan alat ukur untuk mengukur berkali-kali dan menghasilkan data yang sama (Mulyanto dan Wulandari, 2010:97). Pernyataan valid apabila nilai korelasi (kolom Corrected Item-Total Correction) $>0,3$ (Mulyanto dan Wulandari, 2010:125)., reliabilitas terpenuhi manakala nilai Cronbac'h Alpha $>0,6$ (Mulyanto dan Wulandari, 2010:126).

Sebelum dilakukan uji statistik lebih lanjut terdapat pengujian awal yang harus dilakukan terhadap data penelitian yaitu uji asumsi klasik yang terdiri dari uji normalitas, uji multikolinieritas dan uji heteroskedastisitas. Uji normalitas bertujuan untuk menguji apakah dalam model regresi, variabel pengganggu atau residual memiliki distribusi normal. Penggunaan uji $\mathrm{t}$ dan uji $\mathrm{F}$ mengasumsikan bahwa nilai residual mengikuti distribusi normal. Jika asumsi ini tidak dipenuhi maka uji statistik akan tidak valid (Mulyanto dan Wulandari, 2010), uji normalitas dibuktikan melalui One-Sample Kolmogorov-Smirnov Test, jika signifikan $>\alpha$, maka data variabel berdistribusi normal. Untuk lebih memperjelas sebaran data dalam penelitian ini maka akan disajikan grafik normal P-Plot. Dasar pengambilan keputusan normalitas data secara grafis menurut Ghozali (2013:163) yaitu jika data menyebar jauh dari garis diagonal atau tidak mengikuti arah garis diagonal, maka model regresi tidak memenuhi asumsi normalitas.
Uji multikolinieritas bertujuan untuk menguji apakah dalam model regresi ditemukan adanya korelasi antar variabel bebas (independen). Pengujian ini perlu dilakukan karena model regresi yang baik seharusnya tidak terjadi korelasi diantara variabel independen (Ghozali, 2013:105). Metode deteksi yaitu dengan melihat nilai tolerance dan Variance Inflation Factor (VIF). Apabila tidak ada variabel independen yang memiliki nilai tolerance $<0$ , 10 atau nilai $V I F>10$, maka dalam model regresi tidak terdapat multikolinieritas(Ghozali, 2013:106).

Uji heteroskedastisitas bertujuan menguji apakah dalam model regresi terjadi ketidaksamaan variance dan residual satu pengamatan ke pengamatan yang lain. Jika variance dari residual satu pengamatan ke pengamatan yang lain tetap, maka disebut homoskedastisitas dan jika berbeda disebut heteroskedastisitas. Model regresi yang baik adalah yang homoskedastisitas atau tidak terjadi heteroskesdastisitas, cara mendeteksi dengan Uji Glejser dengan probabilitas signifikannya di atas tingkat kepercayaan 5\%, maka dapat disimpulkan model regresi tidak mengandung Heteroskedastisitas.

Pengujian hipotesis dalam penelitian ini menggunakan uji regresi berganda. Uji koefisien determinasi dan uji $\mathrm{F}$ digunakan untuk menguji model penelitian (goodness of fit model), Uji $\mathrm{t}$ digunakan untuk menguji pengaruh masingmasing variabel independen terhadap variabel dependennya. Hipotesis penelitian dikatakan terbukti jika hasil pengujian menunjukkan nilai siginifikansi $<0,05$ artinya ada pengaruh signifikan antara variabel independen dengan variabel dependen.

\section{Hasil Penelitian dan Pembahasan}

Hasil uji validitas menunjukkan nilai korelasi skor item dengan skor total untuk semua pertanyaan $>0,3$ maka seluruh item pernyataan kuisioner untuk seluruh variabel dinyatakan valid. Hasil uji relibilitas menunjukkan nilai cronbach alpha untuk seluruh variabel $>0,6$ 
sehingga dapat disimpulkan bahwa seluruh item adalah reliable (andal).

Hasil uji normalitas menunjukkan bahwa data terdistribusi normal, terlihat dari nilai Kolmogorov-Smirnov $\mathrm{Z}$ sebesar 0,818 dan signifikan pada angka 0,515 berada di atas batas erorr yaitu 0,5 sehingga dapat disimpulkan data terdistribusi normal.

Hasil uji multikolinieritas pada Tabel 1. menunjukkan bahwa variabel-variabel bebas seperti Kompetensi SDM, Teknologi Informasi dan Penerapan Sistem Pengendalian Internal tidak menunjukkan nilai tolerance kurang dari 1,0. Demikian juga dengan hasil perhitungan Variance Inflation Factor (VIF) tidak ada yang nilainya kurang dari 10 sehingga dapat disimpulkan tidak ada multikolinieritas antar variabel bebas dalam model regresi ini.

Tabel 2. Uji Multikolinieritas

\begin{tabular}{lccl}
\hline \multicolumn{1}{c}{ Keterangan } & Tolerance & VIF & \multicolumn{1}{c}{ Keterangan } \\
\hline Kompetensi SDM & .768 & 1.302 & Tidak ada multikolinieritas \\
Teknologi Informasi & .887 & 1.128 & Tidak ada multikolinieritas \\
Penerapan SPI & .826 & 1.210 & Tidak ada multikolinieritas \\
\hline
\end{tabular}

Hasil uji heteroskedastisitas menggunakan Uji Glejser diperoleh nilai signifikansi sebesar 1,000 menurut Gujarati dalam Ghozali (2013:142), hasil penelitian variabel dependen nilai absolutresidual (AbsRes) terhadap variabel independen dengan probabilitas signifikannya di atas tingkat kepercayaan 5\%, maka dapat disimpulkan model regresi tidak mengandung Heteroskedastisitas

Pengujian hipotesis dalam penelitian dilakukan dengan Uji regresi linier berganda. Berdasarkan hasil olah data dengan menggunakan SPSS diperoleh hasil seperti pada Tabel 2.

Tabel 3.Hasil Pengujian Hipotesis

\begin{tabular}{lcccc}
\hline \multicolumn{1}{c}{ Variabel Independen } & B & Std. Error & t hitung & Sig. \\
\hline Kompetensi SDM & .266 & .125 & 2.137 & .036 \\
Teknologi Informasi & .258 & .095 & 2.723 & .008 \\
Penerapan SPI & .193 & .088 & 2.193 & .0826 \\
Constant & 1.206 & .521 & 2.313 & .023 \\
R Square & .299 & & & \\
Adjusted R Square & .271 & & & \\
F hitung & 10.795 & & & \\
Sig. F & $.000^{\mathrm{b}}$ & & & \\
\hline
\end{tabular}

Berdasarkan hasil analisa regresi berganda tersebut dapat dibentuk persamaan regresi linear berganda sebagai berikut:

$$
Y=1.206+0.266 X_{1}+0.258 X_{2}+0.193 X_{3}+e
$$

Interpretasi atas persamaan di atas adalah:

1. Nilai konstanta sebesar 1.206 artinya jika variabel X1 (Kompetensi SDM), X2 (Teknologi Informasi), X3 (Penerapan
SPI) nilainya 0 (tidak dipengaruhi oleh ketiga variabel bebas), maka variabel $\mathrm{Y}$ (Hasil Reviu Audit Intern (Reviu Laporan Keuangan)) nilainya sebesar 1.206.

2. Koefisien regresi variabel Kompetensi SDM sebesar 0.266 menunjukkan Kompetensi SDM berpengaruh positif terhadap Hasil Reviu Audit Intern (Reviu Laporan Keuangan), artinya jika Kompetensi SDM 
mengalami kenaikan satu satuan maka akan meningkatkan Hasil Reviu Audit Intern (Reviu Laporan Keuangan) sebesar 0,266 atau semakin baik Kompetensi SDM maka akan semakin baik pula Hasil Reviu Audit Intern (Reviu Laporan Keuangan) .

3. Koefisien regresi variabel Teknologi Informasi bernilai positif menunjukkan adanya hubungan yang searah dengan Hasil Reviu Audit Intern (Reviu Laporan Keuangan), artinya jika Teknologi Informasi mengalami kenaikan satu satuan maka akan meningkatkan Hasil Reviu Audit Intern (Reviu Laporan Keuangan) sebesar 0,258 atau semakin baik Teknologi Informasi maka akan semakin baik pula Hasil Reviu Audit Intern (Reviu Laporan Keuangan) .

4. Koefisien regresi variabel Penerapan SPI bernilai positif menunjukkan adanya hubungan yang searah dengan Hasil Reviu Audit Intern (Reviu Laporan Keuangan), artinya jika Penerapan SPI mengalami kenaikan satu satuan maka akan meningkatkan Hasil Reviu Audit Intern (Reviu Laporan Keuangan) sebesar 0,193 atau semakin baik penerapan SPI maka akan semakin baik pula Hasil Reviu Audit Intern (Reviu Laporan Keuangan).

Berdasarkan tabel di atas diketahui nilai adjusted $\mathrm{R}^{2}$ sebesar 0,271 , artinya ada hubungan yang sangat rendah antara variabel bebas Kompetensi SDM, Teknologi Informasi dan Penerapan SPI terhadap variabel terikat Hasil Laporan Keuangan. Hal ini berarti hanya sebesar 27,1\% variasi Hasil Reviu Audit Intern (Reviu Laporan Keuangan) dapat dijelaskan oleh variasi dari ketiga variabel bebas Kompetensi SDM, Teknologi Informasi dan Penerapan SPI sisanya sebesar (100\% - 27,1\%) 72,9\% dipengaruhi oleh faktor lainnya yang tidak diteliti dalam penelitian ini. Dari tabel diatas untuk uji $\mathrm{F}$ menunjukkan nilai signifikan sebesar $0,000<\alpha 5 \%$ maka $\mathrm{H}_{0}$ ditolak sehingga dapat disimpulkan bahwa secara simultan ada pengaruh yang signifikan antara Kompetensi SDM, Teknologi Informasi dan Penerapan Sistem Pengendalian Internal secara bersama-sama terhadap Hasil Reviu Audit Intern (Reviu Laporan Keuangan).

Dari hasil uji t dapat disimpulkan sebagai berikut:

1. Untuk variabel Kompetensi SDM (X1) diperoleh nilai $t_{\text {hitung }} 2.137>\quad t_{\text {tabel }} 1.66515$ dengan $\mathrm{p}$ value (sig) sebesar 0,036< $\alpha 5 \%$ artinya Kompetensi SDM (X1) secara parsial mempunyai pengaruh yang signifikan terhadap Hasil Reviu Audit Intern (Reviu Laporan Keuangan) (Y).

2. Untuk variabel Teknologi Informasi (X2) diperoleh nilai $t_{\text {hitung }} 2,723>t$ tabel 1.66515 dengan $\mathrm{p}$ value (sig) sebesar $0,008<\alpha 5 \%$ maka Artinya Teknologi Informasi (X2) secara parsial mempunyai pengaruh yang signifikan terhadap Hasil Reviu Audit Intern (Reviu Laporan Keuangan) (Y).

3. Untuk variabel Penerapan SPI (X3) diperoleh nilai $t_{\text {hitung }} 2.193<t_{\text {tabel }} 1.66515$ dengan $\mathrm{p}$ value (sig) sebesar $0,031<\alpha 5 \%$ artinya Penerapan SPI (X3) secara parsial mempunyai pengaruh yang signifikan terhadap Hasil Reviu Audit Intern (Reviu Laporan Keuangan) (Y).

\section{Pengaruh Kompetensi SDM Terhadap Hasil Reviu Audit Intern (Reviu Laporan Keuangan)}

Hasil uji parsial (uji t) menunjukkan bahwa Kompetensi SDM mempunyai pengaruh yang signifikan terhadap Hasil Reviu Audit Intern (Y). Semakin baik kompetensi SDM, semakin baik pula Laporan keuangan yang dihasilkan sehingga hasil reviu Audit Inter terhadap Laporan keuangan juga akan baik.

Hasil penelitian ini konsisten dengan penelitian yang dilakukan oleh Evicahyani dan Setiawani (2016), Agustiawan dan Rasmini (2016), Kuasa et al., (2014), Nurillah dan Muid (2014), Mahaputra dan Putra (2014), Nugraheni dan Subaweh (2008) yang menyimpulkan bahwa Kompetensi SDM berpengaruh positif 
dan signifikan terhadap Kualitas Laporan Keuangan. Hasil Penelitian ini tidak konsisten dengan penelitian yang dilakukan Komarasari (2016), Karmila et al., (2014), Arfianti dan Kawedar (2011) yang mengungkapkan bahwa Kompetensi SDM tidak berpengaruh signifikan terhadap Kualitas Laporan Keuangan.

Kompetensi SDM adalah faktor penting dalam penyusunan laporan keuangan, sehingga harus dipastikan bahwa SDM di kelola dengan baik agar dapat berkontribusi secara optimal dalam mencapai tujuan organisasi. Variabel kompetensi sumber daya manusia diukur dengan instrument yang dibuat oleh Sukaningrum (2012) dimana terdapat empat indikator yaitu: (1) Pemahaman terhadap peraturan dan standar, (2) Interaksi dengan sistem, (3) Kontrol terhadap SDM, (4) Pendidikan dan training.

\section{Pengaruh Teknologi Informasi Terhadap Hasil Reviu Audit Intern (Reviu Laporan Keuangan)}

Hasil uji parsial (uji t) menunjukkan bahwa Teknologi Informasi berpengaruh yang signifikan terhadap Hasil Reviu Audit Intern (Reviu Laporan Keuangan) (Y).

Hasil penelitian ini konsisten dengan penelitian yang dilakukan oleh Komarasari (2016), Agustiawan dan Rasmini(2016), Karmila et al., (2014), Nurillah dan Muid (2014), yang menyimpulkan bahwa Teknologi Informasi berpengaruh positif dan signifikan terhadap Hasil Reviu Audit Intern (Reviu Laporan Keuangan) . Artinya semakin baik pemanfaatan Teknologi Informasi maka semakin baik Laporan Keuangan yang di hasilkan. Penelitian ini tidak konsisten dengan Arfianti dan (2011) yang menyatakan pemanfaatan teknologi tidak berpengaruh terhadap keandalan pelaporan kueangan.

Pemanfaatan teknologi informasi yang meliputi teknologi komputer, internet dan teknologi komunikasi dalam pengelolaan keuangan satkerakan dapat meningkatkan pemrosesan transaksi dan data lainnya, keakuratan dalam perhitungan, mempercepat proses transmisi data serta penyiapan laporan dan output lainnya lebih tepat waktu. Teknologi Informasi berperan dalam menyediakan informasi yang bermanfaat bagi para pengambil keputusan di dalam organisasi termasuk dalam hal pelaporan, sehingga mendukung proses pengambilan keputusan dengan lebih efektif. Hal ini sesuai dengan cita - cita pemerintah dalam rangka peningkatan kemampuan pengelolaan keuangan yang diatur dalam PP No. 24 tahun 2005 yang mengatur tentang kriteria kualitas informasi yang menjadikan informasi dalam pelaporan keuangan pemerintah mempunyai nilai atau manfaat dalam pengambilan keputusan oleh semua pengguna dan stakeholder.

\section{Pengaruh Penerapan SPI Terhadap Terjadinya Hasil Reviu Audit Intern (Reviu Laporan Keuangan)}

Hasil uji parsial (uji t) menunjukkan bahwa Penerapan SPI mempunyai pengaruh yang signifikan terhadap Hasil Reviu Audit Intern (Reviu Laporan Keuangan) (Y) yang ditunjukkan dengan nilai $t_{\text {hitung }}$ lebih kecil dari $\mathrm{t}_{\text {tabel }}$. Hasil pengujian statististik tersebut menunjukan bahwa semakin baik penerapan SPI maka laporan keuangan yang dihasilkan semakin baik pula, sehingga hasil reviu laporan kueangan oleh pihak Inspektorat Jenderal juga akan baik (tidak ada permasalahan dalam penyajiannya).

Hal ini sejalan dengan pendapat dari Komarasari (2016), Yusniar et al., (2016), Agustiawan dan Rasmini (2016), Nurillah dan Muid (2014), Mahaputra dan Putra (2014), Widyaningsih et al., (2011), Arfianti dan Kaweder (2011) yang menyebutkan bahwa tujuan Penerapan SPI yang baik dapat menunjang laporan keuangan yang berkualitas. Namun penelitian ini tidak dengan penelitian yang dilakukan Karmila et al., (2014) yang mengungkapkan bahwa Penerapan SPI tidak berpengaruh signifikan terhadap Kualitas Laporan Keuangan. 
Pentingnya penerapan SPI ini tercermin dari Peraturan Menteri Keuangan Nomor 14/ PMK.09/2017 tentang Pedoman Penerapan, Penilaian, Reviu Pengendalian Intern atas Pelaporan Keuangan Pemerintah Pusat. Pada Pasal 4 menyatakan bahwa setiap entitas akuntansi dan entitas pelaporan penyusun Laporan Keuangan Pemerintah Pusat (LKPP) harus menerapkan Pengendalian Intern atas Pelaporan Keuangan (PIPK). Pengendalian Intern atas Pelaporan Keuangan (PIPK) adalah pengendalian yang spesifik dirancang untuk memberikan keyakinan yang memadai bahwa laporan keuangan yang dihasilkan merupakan laporan yang andal dan disusun sesuai dengan standar akuntansi pemerintah.

\section{Simpulan, Keterbatasan, dan Implikasi Hasil Penelitian}

Penelitian ini bertujuan untuk memberikan bukti empiris dan menganalisis pengaruh Kompetensi SDM, Teknologi Informasi dan Penerapan Sistem PengendalianInternal terhadap Hasil Reviu Audit Intern (Reviu Laporan Keuangan). Berdasarkan hasil penelitian dapat disimpulkan bahwa kompetensi SDM, teknologi informasi dan penerapan sistem pengendalian internal berpengaruh signifikan terhadap hasil reviu audit intern (reviu laporan keuangan).

Keterbatasan penelitian ini hanya menggunakan tiga variable independen yang terkait dengan hasil reviu laporan keuangan dimana nilai adjusted R2 pada penelitian ini masih tergolong rendah yaitu sebesar 0,271 (27.1\%), sisanya $72,9 \%$ dipengaruhi oleh faktor lainnya yang tidak diteliti dalam penelitian ini misalnya variable Standar Akuntansi Pemerintah, Pengalaman Kerja, dan sistem organisasi, serta data yang digunakanadalah data primer yang berasal dari kuesioner. Seperti yang telah diketahui sebelumnya bahwa, data yang didapatkan dari kuesioner biasanya bersifat subyektif (berdasarkan opini masing-masing Responden) sehingga keobyektifitasannya sering diragukan.
Dari hasil penelitian yang telah dilakukan, ada beberapa saran yang dapat disampaikan bahwa secara parsial terdapat pengaruh yang signifikan antara Kompetensi SDM, Teknologi Informasi dan Penerapan Pengendalian Internal terhadap Hasil Reviu Audit Internal sehingga di harapkan Satuan kerja dapat meningkatkan kemampuan SDM, memaksimalkan pemanfaatan teknologi serta menerapkan sistem pengendalian internal dengan baik dalam pengeloalaan keuangan satker. Sebagaimana dijelaskan sebelumnya, hasil penelitian menunjukkan hubungan antara Kompetensi SDM, Teknologi Informasi dan Penerapan Pengendalian Internal. Secara teoritis, hal ini dapat mendorong arah riset selanjutnya untuk lebih spesifik meneliti faktor-faktor yang mempengaruhi hasil reviu laporan keuangan sehingga dapat menghasilkan teori baru khususnya dalam meningkatkan Hasil Reviu Audit Internal

\section{Daftar Referensi}

Agustiawan, Nyoman T., Rasmini, Ni Ketut, (2016), Pengaruh Sistem Berbasis Akrual, TI, Dan SPIP Pada Kualitas Laporan Keuangan Dengan Kompetensi SDM Sebagai Moderasi, E-Jurnal Ekonomi dan Bisnis Universitas Udayana, tahun 2016, Halaman 3475 - 3500.

Arfianti, Kawedar, (2011), Analisis FaktorFaktor Yang Mempengaruhi Nilai Informasi Pelaporan Keuangan Pemerintah Daerah Studi pada Satuan Kerja Perangkat Daerah di Kabupaten Batang), Jurnal Akuntansi Universitas Diponegoro Semarang, tahun 2011.

Cats-Baril, W.,Thompson, Ronald, (2003). Information Technology and Management. McGraw-Hill, New York.

Evicahyani, Sagung Inten., Setiawina., Nyoman D., (2016), Analisis Faktor-Faktor Yang Mempengaruhi Kualitas Laporan Keuangan Pemerintah Daerah Kabupaten Tabanan, E-Jurnal Ekonomi dan Bisnis Universitas Udayana tahun (2016), Halaman 403 - 428. 
Ghozali, (2013), Imam, Aplikasi Analisis Multivariate dengan Program IBM SPSS 21 Update PLS Regresi, Edisi 7, Badan Penerbit Universitas Diponegoro, Semarang.

Kadir, Abdul.,Triwahyuni , Terra CH, (2003), Pengenalan Teknologi Informasi. Yogyakarta: Andi Offset.

Karmila., Tanjung, Amries R., Darlis E., (2014), Pengaruh kapasitas Sumber Daya Manusia, Pemanfaatan Teknologi Informasi, dan Pengendalian Intern Terhadap Keterandalan Pelaporan Keuangan Pemerintah Daerah Studi Pada Pemerintah Provinsi Riau), Jurnal Sorot, Volume 9 No.1 April 2014, Halaman 25-42.

Komarasari, Warih, (2016), Pengaruh Kapasitas Sumber Daya Manusia, Pemanfaatan Teknologi Informasi Dan Pengendalian Intern Akuntansi Terhadap Keterandalan Pelaporan Keuangan Daerah Pada SKPD Kabupaten Bantul Bagian Akuntansi dan Keuangan), Jurnal Universitas PGRI Yogyakarta, Tahun (2016)

Kuasa., Nadirsyah., Abdullah, Syukriy, (2014), Pengaruh Kompetensi Pejabat Pengelola Keuangan, Regulasi Dan Pengawasan Keuangan Daerah Terhadap Kualitas Laporan Ke uanganSkpd Di Lingkungan Pemerintah Kabupaten Simeulue, Jurnal Magister Akuntansi, Volume 5 No. 2 Mei 2016, Halaman 47-56.

Lestari, Anita Mega, (2013), Pengaruh Sumbe Daya Manusia, Sistem Pengendalian Intern dan Standar Akuntansi Pemerintahan Terhadap Kualitas Laporan Keuangan, Tesis Universitas Pancasila.

Mahaputra , I Putu Upabayu Rama., Putra, I Wayan, (2014), analisis faktor-faktor yang memengaruhi kualitas informasi pelaporan keuangan pemerintah daerah, E-Jurnal Akuntansi Udayana 8.2 2014, Halaman 230-244.

Mulyanto, H., Wulandari, A, (2010), Penelitian; Metode dan Analisis, CV Agung, Semarang. Nugraheni, Purwanianti.,Subaweh, Imam,
(2008), Pengaruh Penerapan Standar Akuntansi Pemerintahan Terhadap Kualitas Laporan Keuangan, Volume 13 No. 1 , April 2008, Halaman 48-58.

Nurillah, As Syifa., Muid, Dul (2014), Pengaruh Kompetensi Sumber Daya Manusia, Penerapan Sistem Akuntansi Keuangan Daerah SAKD), Pemanfaatan Teknologi Informasi, dan Sistem Pengendalian Intern Terhadap Kualitas Laporan Keuangan Pemerintah Daerah studi empiris pada skpd kota depok), Diponegoro Journal of Accounting, Volume 1 No. 1 2014, Halaman $1-13$.

Peraturan Menteri Keuangan Nomor 255 Tahun (2015) tentang Standar StandarReviu Laporan Keuangan Kementerian/Lembaga. Peraturan Pemerintah Nomor 56, (2005), tentang Sistem Informasi Keuangan.

Peraturan Pemerintah Nomor 60, (2008), tentang Sistem Pengendalian Intern Pemerintah.

Peraturan Pemerintah Nomor 8, (2006), tentang Pelaporan Keuangan dan Kinerja Instansi Pemerintah.

Sukmaningrum, Tantriani, (2012), Analisis Faktor-Faktor yang Mempengaruhi Kualitas Informasi Laporan Keuangan Pemerintah Daerah Studi Empiris pada Pemerintah Kabupaten dan Kota Semarang, Tesis. Universitas Diponegoro.

Widyaningsih, Aristanti.,Triantoro, Alvian., Wiyantoro Lili Sugeng, (2014), Hubungan Efektifitas Sistem Akuntansi Keuangan Daerah Dan Pengendalian Intern Dengan Kualitas Akuntabilitas Keuangan: Kualitas Informasi Laporan Keuangan Sebagai Variabel Intervening, Seminar Nasional Akuntansi XIV Aceh, 2011.

Wilkinson, W Josep., Michael, J Cerullo.,Vasant, Raval., Bernad Wong on Wing, (2000), Accounting Information Sysistem : Essential Concepts and Application. Fourt Edition. John Wiley and Sons.Inc.

Yusniar, Darwanis., Abdullah, Syukriy, (2016)

Pengaruh Penerapan Sistem Akuntansi 
Jurnal Riset Akuntansi dan Perpajakan JRAP Vo. 4, No. 2, Desember 2017, hal 208-221 ISSN 2339 - 1545

Pemerintahan Dan Pengendalian Intern Terhadap Good Governancedan Dampaknya Pada Kualitas Laporan Keuangan Studi Pada SKPA Pemerintah aceh), Jurnal Magister Akuntansi, Volume 5 No. 2 Mei 2016, Halaman 100 - 115. 